\title{
Migrated Archives: The Unfinished Business
}

\section{Nathan Mnjama}

\begin{abstract}
Finding solutions to the problems associated with the retrieval of records removed from their countries of origin to western capitals have alluded African nations ever since they gained independence. Despite the efforts made by African countries to locate and retrieve migrated archives to their countries of origin, there is no hope that these problems will be resolved within the foreseeable future. This paper is based on international laws governing the transfer of power from a predecessor government to a successor government, as well as the United Nations Human Rights Charter, which includes access to records and information as a basic human right to be enjoyed by all. Based on a review of literature and other documentary sources, this article begins by identifying the broad categories that constitute migrated archives. It explains the impact that has been caused by the removal of records from their countries of origin and past efforts made by African countries to locate and to retrieve migrated archives to their countries of origin. The paper further discusses some of the critical factors that have to be addressed if African countries are to undertake any meaningful retrieval of migrated archives programmes. Finally, it concludes by stating that dealing with migrated archives will remain a contentious issue for several years to come and urges African countries to explore multilateral arrangements for solving the problem as no single solution may be acceptable to all the countries involved in migrated archives.
\end{abstract}

Keywords: Migrated archives, Restitution of archives, Disputed Archives, Archival Disputes.

\section{Introduction}

African countries have suffered immensely from the illegal transfer of some of their archival heritage to their former colonial masters. As African states were gaining independence, they began to realise that they had not only inherited 


\section{Nathan Mnjama}

weak archival institutions from their former colonial masters, but that some valuable records were also missing. For reasons they did not understand, some of these records had been destroyed while others had been transferred to European capitals. Failure to transfer all the records created by the colonial administration to the successor governments meant that these newly independent states had no access to valuable records documenting their cultural and historical experiences under the colonial rule. African countries were not the only countries that experienced this phenomenon. Lesinger, one of the celebrated American Archivists, observed that

the history of mankind is replete with examples of archives that have been unjustly transferred from one country to another. At the present time the developing countries of the third world have an urgent pressing need for access to the archival sources documenting their history which are located abroad primarily, but not exclusively in the custody of the former metropolis governments (Lesinger 1982:1).

However, the problem of archives removed from their countries of origin is perhaps more evident in Africa than elsewhere in the world, and has been an issue of major concern to African governments for a considerable number of years now.

Efforts to resolve issues associated with the return of migrated archives to their countries of origin have not achieved much success as these records continue to remain in the custody of western powers. Namihla $(2015: 28)$ the former Director of Namibia Library and Archives Services noted that 'the issue of repatriation of migrated archives remains a highly contentious issue and may be larger than previously acknowledged'. Why should this be so? Several reasons may be advanced as to why this problem remains unresolved. In the first instance, the issue of migrated archives was not revealed to the incoming newly independent states by the departing colonial masters leaving them to discover for themselves what records were unavailable locally or had gone missing. Secondly, as the successor governments began to discover that major gaps existed in their archives and records holdings, they received minimal or no support from their former colonial masters in locating the whereabouts of these records. Thirdly, at the international level, efforts by the United Nations Educational, Scientific and Cultural Organization (UNESCO), and the International Council on Archives (ICA) to address problems related to 
migrated archives have been frustrated by the western powers who refused to ratify important legal instruments such as the Vienna Convention on the Law of Succession of States in respect of State Property, Archives and Debts that was formally adopted in Vienna, Austria in April 1983. Fourthly, even with the enactment of Freedom of Information in most Western countries, these governments have failed to disclose fully details relating to records transferred from the colonies to the metropolitan cities. For instance, even after the opening of some of the migrated archives that were held at Hanslope Park in London, for public inspection, Cobain (2013) observed that:

Freedom of information campaigners believe that the hoarding of such a huge amount of papers is symptomatic of a culture of secrecy and retention at the Foreign Office and across many other UK government departments. Maurice Frankel, director of the Campaign for Freedom of Information, an NGO that works to ensure the Freedom of Information Act is properly implemented, said: 'The FoI system depends on people knowing what they hold and being transparent about what they hold'.

\section{Understanding Archives}

Well preserved and properly managed archives serve various purposes. The Canadian Dominion Archivist Sir Arthur Doughty once argued that:

Of all the national assets, archives are the most precious: they are the gift of one generation to another, and the extent of our care of them marks the extent of our civilization (Canadian Council on Archives 2012).

Archives and particularly public archives serve as the collective memory of the nation. This is a view that was supported by Rhoads (1983:1) when he argued that archives serve as the collective memory of the nation and enable the nation to plan intelligently for the future based on the awareness of past experience. Archives also document obligations and commitments of the government and serve as evidence of the rights and entitlement of the citizens. Rhoads stressed that 'as a source of national history, the archives can become a powerful influence in fostering people's understanding of itself and in creating a sense 


\section{Nathan Mnjama}

of national identity' (Rhoads 1983:1). That archives are a valuable resource to national identity was perhaps best summed up by Bostock (n.d.) when he wrote saying 'the common memories stored and maintained in archives are not only essential for continued organisational survival but also essential to the development and maintenance of identity'. He further suggested that 'problems of identity must be resolved if the destruction of communities, organisations and even states is to be avoided'. Bostock (n.d.) came to the conclusion that,

without a store of information, every community would have to relearn from costly experience the rules of survival: physical, psychological, organisational, legal, philosophical, and spiritual. While archives are essential to continuity, the actual medium of storage is highly variable, having been at various times, stone, cellulose, metal, paper, celluloid, optical, magnetic, electronic or simply oral.

The importance of archives to nations, especially developing countries, was clearly stated by Bedjaoui (1976) an international jurist concerned with the rights and problems of newly independent nations, whose public records and archives had been alienated from their territorial provenance during colonial rule, when he said 'While one cannot conceive of a state without a navy, it is impossible to imagine one without a currency, without a treasury, without funds, and without archives'. In summarising the value and uses of state archives, he commented on their essential nature for the administration of a community:

They both record the management of State affairs and enable it to be carried on, while at the same time embodying the ins and outs of human history .... Secret or public, they constitute a heritage and a public property which the State generally makes sure is inalienable and imprescriptible.

In the preamble to the Universal Declaration on Archives (2012) it was emphasising that,

Archives are a unique and irreplaceable heritage passed from one generation to another ..... They are authoritative sources of information underpinning accountable and transparent administrative actions. 
They play an essential role in the development of societies by safeguarding and contributing to individual and community memory. Open access to archives enriches our knowledge of human society, promotes democracy, protects citizens' rights and enhances the quality of life.

According to Sir Seretse Khama, the first President of Botswana, 'a nation without its archives is a body without a soul' (Parsons 2006:667). It can therefore be argued that archives and particularly public archives serve as a collective memory of the nation. They are a national resource documenting the country's collective memory showing its culture, traditions, aspirations, as well as its past failures and successes. The significance of archives to the nation was stated by the Archives-Libraries Committee Resolution on Migrated Archives (1977:1) which stated that,

Archives are recognized as an essential part of any nation's heritage providing documentation not only of the historical, cultural, and economic development of a country, thereby providing a basis for a national identity, but also serving as a basic source of evidence needed to assert the rights of individual citizens.

The Archives-Libraries Committee Resolution on Migrated Archives (1977) went further to state that,

Every national community has the right to an identity acquired from its history. In the name of human solidarity, national communities are required to assist each other in the search for historical truth and continuity. Military and colonial occupation should grant no particular right to retain records acquired by virtue of such occupation.

Despite such strong statements, many African countries continue to operate without access to records that were unjustly transferred to western capitals.

\section{Theoretical Framework}

This study is anchored on international laws on succession of states. According to Kumar (1991: 2) state succession denotes the idea of replacement of one state or states by another state or states, over a given territory as a result of 


\section{Nathan Mnjama}

some of the political developments which may present different features, such as cession, secession, annexation, fusion merger etc. Kumar (1991) further argued that,

the replacement of a state or states by a state or states over a given territory results in the transfer, not only of the territory in physical sense along with the people inhabiting it, but also affects the existing rights and the obligations of the states concerned in relation to the territory affected by the change.

Kumar (1991:4) observed that the area of law of state succession is uncertain, ambiguous, and controversial substantially, and it is a little difficult to enumerate the specific rights and obligations which pass to the successor state and the ones which do not pass. This is particularly true when the law of succession is applied to the succession of state property such as archives. Kecskemeti (2017) the former Secretary General of the International Council on Archives (ICA) indicated that treaties relating international laws on succession of states are governed by four principles which are specific to archives. These are:

(a) The predecessor state gives to the successor state the documents necessary for exercising sovereignty and ensuring administrative continuity. The list of archives to be transferred or duplicated is established by agreement between the two parties.

(b) The archives displaced during the period that the state was dependent are returned when the state becomes independent again.

(c) Archives seized and displaced during war are returned at the end of hostilities to the power against whom the war was being waged.

(d) archives of a provisional occupying military power would remain the property of the occupying power (Kecskemeti 2017:11).

According to Article 10 of the Vienna Convention on Succession of States in respect of State Property, Archives and Debts (1983), the effective date for the transfer of state property (including archives) is,

Unless otherwise agreed by the States concerned or decided by an appropriate international body, the date of the passing of State property of the predecessor State is that of the succession of States. 
Article 21 of the same Convention states that,

The passing of state archives of the predecessor state entails the extinction of the rights of that State and the arising of the rights of the Successor State to the State archives which pass to the Successor State, subject to the provisions of the articles in the present Part.

Contrary to common practice under the Law of succession of states, the above principles were not observed when many colonial states gained independence from their colonial masters.

Even though issues of migrated archives are anchored on international laws governing the transfer of power, problems associated with migrated archives are a human right that the United Nations Commission on Human Rights has sought to address over the years. Between 1985 and 1996, Louis Joinet was appointed by the Commission on Human Rights as Special Rapporteur, on various aspects touching on serious violations of economic and cultural rights (United Nations, Economic and Social Council 1997). Joinet submitted his report in August 1997 in which he proposed that 'The right to know implies that archives must be preserved, especially during a period of transition'. Joinet further suggested that in order to ensure that records covering human rights violations and abuses are collected and preserved:

(a) Protective and punitive measures against the removal, destruction or misuse of archives must be put in place;

(b) Establishment of an inventory of available archives, including those kept by third countries must be undertaken in order to ensure that they may be transferred with those countries' consents and, where applicable, returned;

(c) Adaptation to the new situation of regulations governing access to and consultation of archives, in particular by allowing anyone they implicate to add a right of reply to the file (United Nations. Economic and Social Council 1997).

The Joinet principles were replaced in 2005 with a new set of principles commonly referred to as the 'Updated Set of Principles for the protection and 
promotion of human rights through action to combat impunity' commonly referred to as the Orentischer Principles. The preamble to the Updated Set of Principles for the protection and Promotion of Human Rights through Action to Combat Impunity defines archives as,

... collections of documents pertaining to violations of human rights and humanitarian law from sources including:

(a) national governmental agencies, particularly those that played significant roles in relation to human rights violations;

(b) local agencies, such as police stations, that were involved in human rights violations;

(c) state agencies, including the office of the prosecutor and the judiciary, that are involved in the protection of human rights; and

(d) materials collected by truth commissions and other investigative bodies (United Nations 2005).

The Orentlicher principles against impunity provides avenues for victims' right of access to records about themselves and their relatives held by various state organs such as the intelligence, the military and the police. The principles also vest the responsibility of preserving such records with the state or a suitable agency. The major Orentlicher principles relating to the rights to access archives in order to protect human rights are archives reproduced below.

\subsection{THE RIGHT TO KNOW}

\section{A. General principles}

\section{PRINCIPLE 2. THE INALIENABLE RIGHT TO THE TRUTH}

Every person has the inalienable right to know the truth about past events concerning the perpetration of heinous crimes and about the circumstances and reasons that led, through massive or systematic violations, to the perpetration of those crimes. Full and effective exercise of the right to the truth provides a vital safeguard against the recurrence of violations.

\section{PRINCIPLE 3. THE DUTY TO PRESERVE MEMORY}

A people's knowledge of the history of its oppression is part of its heritage and, as such, must be ensured by appropriate measures in fulfilment of the State's 
duty to preserve archives and other evidence concerning violations of human rights and the humanitarian law and to facilitate knowledge of those violations. Such measures shall be aimed at preserving the collective memory from extinction and, in particular, at guarding against the development of revisionist and negationist arguments.

\section{PRINCIPLE 4. THE VICTIMS' RIGHT TO KNOW}

Irrespective of any legal proceedings, victims and their families have the imprescriptible right to know the truth about the circumstances in which violations took place and, in the event of death or disappearance, the victims' fate.

\section{PRINCIPLE 5. GUARANTEES TO GIVE EFFECT TO THE RIGHT TO KNOW}

States must take appropriate action, including measures necessary, to ensure the independent and effective operation of the judiciary, to give effect to the right to know. Appropriate measures to ensure this right may include nonjudicial processes that complement the role of the judiciary. Societies that have experienced heinous crimes perpetrated on a massive or systematic basis may benefit in particular from the creation of a truth commission or other commission of inquiry to establish the facts surrounding those violations so that the truth may be ascertained and to prevent the disappearance of evidence. Regardless of whether a State establishes such a body, it must ensure the preservation of, and access to, archives concerning violations of human rights and humanitarian law.

\section{B. Preservation of and access to archives bearing witness to violations PRINCIPLE 14. MEASURES FOR THE PRESERVATION OF ARCHIVES}

The right to know implies that archives must be preserved. Technical measures and penalties should be applied to prevent any removal, destruction, concealment or falsification of archives, especially for the purpose of ensuring the impunity of perpetrators of violations of human rights and/or humanitarian law.

\section{PRINCIPLE 15. MEASURES FOR FACILITATING ACCESS TO ARCHIVES}

Access to archives shall be facilitated in order to enable victims and their relatives to claim their rights. Access shall be facilitated, as necessary, for 
persons implicated, who request it for their defence. Access to archives should also be facilitated in the interest of historical research, subject to reasonable restrictions aimed at safeguarding the privacy and security of victims and other individuals. Formal requirements governing access may not be used for purposes of censorship.

\section{PRINCIPLE 16. COOPERATION BETWEEN ARCHIVE DEPARTMENTS AND THE COURTS AND NON-JUDICIAL COMMISSIONS OF INQUIRY}

Courts and non-judicial commissions of inquiry, as well as investigators reporting to them, must have access to relevant archives. This principle must be implemented in a manner that respects applicable privacy concerns, including in particular assurances of confidentiality provided to victims and other witnesses as a precondition of their testimony. Access may not be denied on grounds of national security unless, in exceptional circumstances, the restriction has been prescribed by law. The Government has demonstrated that the restriction is necessary in a democratic society to protect a legitimate national security interest, and the denial is subject to independent judicial review.

\section{PRINCIPLE 17. SPECIFIC MEASURES RELATING TO ARCHIVES CONTAINING NAMES}

(a) For the purposes of this principle, archives containing names shall be understood to be those archives containing information that makes it possible, directly or indirectly, to identify the individuals to whom they relate;

(b) All persons shall be entitled to know whether their name appears in State archives and, if it does, by virtue of their right of access, to challenge the validity of the information concerning them by exercising a right of reply. The challenged document should include a cross-reference to the document, challenging its validity and both must be made available together whenever the former is requested. Access to the files of commissions of inquiry must be balanced against the legitimate expectations of confidentiality of victims and other witnesses testifying on their behalf in accordance with principles 8 (f) and $10(\mathrm{~d})$.

PRINCIPLE 18. SPECIFIC MEASURES RELATED TO THE RESTORATION OF OR TRANSITION TO DEMOCRACY AND/OR PEACE

(a) Measures should be taken to place each archive centre under the responsi- 
bility of a specifically designated office;

(b) When inventorying and assessing the reliability of stored archives, special attention should be given to archives relating to places of detention and other sites of serious violations of human rights and/or humanitarian law such as torture, in particular when the existence of such places was not officially recognised;

(c) Third countries shall be expected to cooperate with a view to communicating or restituting archives for the purpose of establishing the truth (United Nations 2005)

Based on the above discussion, it can be seen clearly, that this paper is based on international laws governing the transfer of state property including archives and on the Diane Orentlicher Principles which reaffirms access to archives as a human rights issue. This paper, therefore, seeks to understand what constitutes migrated archives, the importance of migrated archives to communities from where they have been removed from, efforts that African governments have made to gain access to, or have records removed from their territories returned, and the challenges that they continue to face in locating and retrieving their migrated archives. The central argument advanced in this paper is that the removal of ... by colonial governments from the colonies was and still remains a gross violation of the rights of the local communities from where these records were removed from (Mnjama 2008).

\section{Methodology}

This paper is based on extensive review of literature on the subject of migrated archives. The review of literatures includes journal articles, papers presented in learned conferences, book chapters. The paper also draws from experiences by the author who since 1979 has been involved with issues of migrated archives, first as one of the archivists from the Kenya National Archives who participated in the initial surveys to locate Kenya's manuscripts held in the United Kingdom (UK).; and later on, the author was seconded to the Kenya High Commission in London to implement Kenya's Copying Project of records held in the UK. The author participated in the discussions that resulted in the development of Vienna Convention on the Law of Succession of States in Respect of State Property, Archives and Debts (1983), which was ratified by most developing counties but rejected by the Western Powers. The author is 


\section{Nathan Mnjama}

also a current member of the International Council on Archives (ICA) on Shared Archival Heritage (EGSAH). The reviewed literature suggests that only Kenya, Ghana, Zimbabwe, Malawi, and Botswana have so far undertaken surveys of records held in foreign countries relating to their countries. The section that follows provides a broad overview of what constitutes migrated archives.

\section{Migrated Archives Defined}

A great of deal of misunderstanding exists among politicians as well as archivists on what constitutes migrated archives. This misunderstanding stems from the lack of understanding what really falls under the category of migrated archives and what records might not be available locally or where such records might be held. Hence, it is of critical importance that the term 'migrated archives' is defined. The Society of American Archivists (2005) Glossary of Archival and Records Terminology defines migrated archives as 'The archives of a country that have moved from the country where they were originally accumulated; removed archives'. According to Nsibandze (1996:86), migrated archives are archives in exile or archives transferred unjustly (removed) from one country to another. On the other hand, Garaba (2011:34) argued that 'whether one employs the term 'fugitive archival material', or 'missing documents', 'migrated archives', 'removed' or 'displaced archives', 'expatriate archives', 'disputed archival claims', ‘joint archival heritage', 'shared archival heritage' etc. the common factor is that they are not where they are supposed to be, in their rightful place of custody. To Danielson (2010) cited in Winn (2015:7), displaced archives are 'archival material that have been lost, seized, requisitioned, confiscated, purchased under duress or otherwise gone astray'.

Commenting on displaced archives, Winn (2015:7) noted that, it is generally understood that the major concern related to migrated archives is that 'at least one party feels materials were removed illicitly'. This is a view that is shared by Lowry (2018), who argued that the distinguishing factor when describing and defining migrated archives is that 'displaced archives' are records that have been removed from the context of their creation and where the ownership of the records is disputed. Studies conducted by the International Council on Archives indicate that migrated archives are a result of various factors such as: 
(a) changes in sovereignty over a given territory without the creation of a new State;

(b) transfers which took place during wars, or as an effect of military occupation;

(c) the emergence of new States through the splitting of former political entities;

(d) the effects of colonization and decolonization, which require consideration of the following categories of archives:

(i) archives created and retained in the metropolitan countries.

(ii) archives created in the colonies and transferred to other colonies.

(iii) archives of a colonial administration created in the former colony and removed to the metropolitan country at the time of independence.

(iv) archives of a regional colonial administration which relate to more than one new independent State.

(v) archives created in the colonies during the metropolitan administration and inherited now successor States (International Council on Archives 1995:35).

Leisinger (1982), observed that migrated archives may be grouped into five different categories. The first category consists of records that were created and maintained originally by various government agencies of the colonial powers in their own home countries. Examples of these include records from the War Office, The Colonial Office, and the India Office, etc. Many of these agencies had supervisory or administrative roles in the coordination of colonial administration. Strictly speaking, these records were created in the metropolitan cities and at no stage were they removed from the colonies. Writing on the 'National Archives of Malawi and the Problem of Migrated Archives, Mwiyeriwa (1982: 34) the then Chief Archivist of Malawi noted that a large part of Malawian archives now held in the UK are a result of regular correspondence between the colonial administrator in Malawi and those in the Colonial Office in the UK. This supports the argument that this category of archives does not fall into the strict category of archives as they have never migrated from their original place of creation.

The second category of records that are often included under archival 


\section{Nathan Mnjama}

claims include records of colonial administration created in the colonies but transferred to the European metropolitan cities at the dawn of independence. Strictly speaking, this category constitutes what rightfully may be termed as migrated archives as these records were created in the colonies and were removed physically from the colonies to Europe. That records were physically removed from the colonies to Western capitals is not a secret. Hiribarren (2017:77) argued that 'the European powers routinely displaced archives during the decolonization years. With or without a legal framework, France, Belgium, and the Netherlands did not hesitate to transfer documents from their former colonies to the metropole'.

In the case of the former German colonies, several records were transferred to Germany after the First World War when Germany was defeated by the Allied Powers (Namihla 2015:28). As for Britain, available evidence indicates that the removal of records from the colonies to London was sanctioned by the Colonial Office in London and was conducted in a systematic manner over the years. Thus, it can be argued that on the whole, colonial administration paid little or no attention to the development of archival services to the extent that on the eve of independence of many African countries, archival services in Africa were still at their infancy. Mazikana (1997:30) argued that

While some countries in North Africa have archival institutions that date back several centuries, most sub-Saharan countries established national archives only after the Second World War. Benin, Burkina Faso, Namibia, Senegal, South Africa and Zimbabwe are among the few exceptions in sub-Saharan Africa that established national archives before 1950 .

Kagombe (1977:1) the former Director of the Kenya National Archives and Documentation Services observed that:

The status of archives in Africa is not encouraging. It is a little known and neglected area but which few Africans seem to care about, leaving concern to foreigners who are keen on researching as well as taking our valuable documents out of the country. This status is a result of negligence, lack of knowledge and often lack of funds in our respective governments. Many African countries inherited a British or French legacy, which often created various obstacles in establishing proper 
archives. This was partly because the British and the French were interested in keeping the records for use in their own countries, and did not think future independent states might need them or even if they did, it might not be necessary for them to know why and how certain things were created or decided upon for it be self- incriminating.

As early as 1929, a Circular letter sent to the colonies and signed by the Colonial Secretary L S Amery (1929) stated:

If there are any early official records in your custody which it considered essential to remove in order to ensure their preservation, I shall be glad if you will furnish me with detailed particulars including the lineal space which they would occupy. In the case of older colonies, documents of a date anterior to that of the early part of the $19^{\text {th }}$ Century might be considered in the first instance, but the case of the territories more recently acquired, at/by? the end of $1878 \mathrm{might}$ form a convenient division, as records up to that date are generally open to the public.

From the above circular letter, it is evident that the major reason for recommending the transfer of records from the colonies to London is that the colonies lacked adequate storage facilities for the long-term preservation of records selected for permanent preservation. The same circular letter also indicates that the Colonial Office in London had no plans for setting up archival institutions in the colonies, and preferring to have all valuable archival collection transferred to London,

The extent to which the above instructions were followed in the colonies is yet to be determined, but there is every likelihood to suggest that records from tropical regions might have been transferred to Britain under the above arrangements as many of them were held under poor environmental conditions in the colonies as archival institutions/repositories were yet to be established or were at their infant stage of development.

The reasons for the removal of records to European capitals were varied and as Ramokate (2004:1) has rightly argued the colonial powers took away some 


\section{Nathan Mnjama}

of the records because they were 'too sensitive and might cause unrest if left with the natives'. He added that that the colonial powers had a right to the records because they created them. The Cary Report on the release of colonial administration files indicates that the removal of records to Britain on the eve of independence was based on Colonial Office Guidance telegram of 3 May 1961 on the disposal of classified records and accountable documents in which it was clearly stated that the following records should not be passed to successor governments. Records that:

(a) might embarrass Her Majesty's Government (HMG) or other governments.

(b) Might embarrass members of the police, military forces, public servants and others e.g. police informers.

(c) Might compromise sources of intelligence information.

(d) Might be used unethically by successor ministers in the successor government (The Foreign and Commonwealth Office 2011).

Macphee (2012) asserted that painstaking measures were taken to prevent postindependence governments from learning that the watch files had ever existed. One instruction stated that 'The legacy files must leave no reference to watch material. Indeed, the very existence of the watch series, though it may be guessed at, should never be revealed'. [Therefore, when] a single watch file was to be removed from a group of legacy files, a 'twin file' - or dummy -was to be created to insert in its place. If this was not practicable, the documents were to be removed en masse. The fact that western powers sought to conceal any incriminating evidence was also supported by Rawlings (2015) who argued that,

Colonial authorities did have plenty to be embarrassed about. Files show that in addition to torture, maltreatment of detainees and human rights violations in Kenya, the UK was involved in the forced deportation of the Ilois from their island homeland of Diego Garcia to make way for an American military base, considered testing poison gas in Botswana, and proposed the 'elimination' of insurgents in Malaya during its anti-communist 'emergency' (1948 - 1960).

Besides official records that were transferred to European capitals, Mukula 
(1982) the Director of Zambia National Archives observed that there are other records which were transferred to European capitals by colonial administrators in breach of the codes of regulations which prohibited them from removing official records from public institutions and carrying them to their respective countries when their terms of office came to an end. Mukula (1982) noted that,

these officers took or sent to their home countries official correspondence, reports and findings which can now be found listed in the Manuscript Collection of Africana in Rhodes House Library, Oxford. There is no good reason why these records cannot be repatriated, they are public records, although they have been classified as historical manuscripts.

Similar sentiments were expressed by The Chief Archivist of Malawi, the late Mr Steve Mwiyeriwa (1982:33 - 34) who pointed out that:

If there are any archives in Britain or elsewhere which migrated from Malawi, then this must have been as a result of selfish action by a handful of individuals rather than official policy. The fact that they were taken from Malawi reveals the inadequacy of the archives law at the time of exportation. This, however, cannot be said of one major type of records. Christian Missions in Scotland and Rome possesses $\mathrm{m}$ aterial which was actually created in Malawi.

Hiribarren (2017: 82) came to the conclusion that today,

Displaced archives have nonetheless become the symbol of a lack of accountability of European governments and of a certain culture of secrecy. Their very existence not only challenges national narratives but also undermines democratic governments' transparency and accountability.

Hiribarren (2017:83) went on to argue that,

the displaced archives are a physical expression of the culture of secrecy of most European governments and their existence challenges the legitimate rights of European citizens to a certain type of demo- 
cratic accountability (Hiribarren 2019:83).

In essence "the removal of records from colonial states and their migration to Western capitals in order to conceal the truth concerning illegitimate practices and injustices in the colonies ...'.. This indeed gives the impression that Western States did not wish to operate in a transparent and accountable manner as far as some of their operations in colonies is concerned.

The third category that may be included under the broad category of archival claims relates to records that were created in one territory, but somehow found their way into another territory. Examples of such records include records of the High Commissioner for Basutoland (now Lesotho), Bechuanaland, and Swaziland, initially held in Cape Town, but later transferred to Salisbury (Harare) in 1948 (Mukula 1982).

The fourth category of records belongs to the archives of regional colonial bodies which either collapsed during the colonial period or soon after independence leaving the records relating to the different states in one country. Examples of such records include the records of the defunct East African Community (Mnjama 2000) and those of the Federation of Rhodesia and Nyasaland (Mukula 1982). In the case of the records of the defunct East African Community, the records of the East African Community have remained in Arusha Tanzania where the community's headquarters was based, while those of the various regional bodies have been inherited by the national archives of the three East African partner states. With the breakdown of the Federation of Rhodesia and Nyasaland the records were handled in a different manner. The records that pertained to more than one state were retained in Harare, while those records that related specifically to the various countries were returned to the national archives of the partner states (Mazikana 1982).

The fifth category of records relates private papers of individuals and various lorganisations that had contact with the African peoples. The records of various church missionary organizations, travel accounts of European explorers, anthropologists, and others contain valuable information on African peoples. Many of these records are now held in foreign university libraries, local records offices and in some cases the whereabouts of such records remain unknown. In some cases, these records form part of the core African Studies African programmes. Kenya has made several efforts to locate the whereabouts of its unofficial records held in U.K. The results of these surveys have now been published. 
The six category of migrated archives relates to records created by various individuals and liberation movements whose members were forced into exile during the struggle for independence. The records of such individuals as well as movements such as the African National Congress (ANC) of South Africa and other national movements in the Southern African region cannot be ignored. Garaba (2011) argued that liberation archives are of differing types and status, reflecting the diverse nature of the struggle itself and ranges from written, oral, and audio to visual materials. Locating such records has often proved difficult as the offices of such movements were often raided or destroyed. In some other cases, these records have remained in those countries where the freedom fighters had sought refuge. In the absence of manuscript registers, it is often very difficult to establish the whereabouts of these records.

Finally, there is one category of papers that is often not included in the list of records that have left their countries of origin. These records relate to the many collections that have been built by scholars conducting research in Africa many of who have deliberately failed to comply with the regulations governing authorisation to carry out research in many of the African countries. In Botswana, for instance, until recently, there were over 500 foreign scholars who were yet to deposit copies of their research findings with the Botswana National Archives. Others scholars have also been known to have stolen records from African... while conducting research in those countries. The Director of Zambia National Archives in his submission to the $7^{\text {th }}$ ECARBICA Conference in Zimbabwe stated that:

Now I must say something about records that have been removed from Zambia by unscrupulous researchers who claim to be professors and historians but are dangerous wolves of history, double dealers pretending to write the history of independent countries but depriving them of their historical legacy. An example is the removal of the papers of the veteran politician and farmer Sir S Gore Brown. Before his death Gore Brown had written 'I hope this estate where my family and I live happily among the people of another race may serve as a home for my descendants for many generations, if not centuries'. But how can they continue to live in the absence of their valuable records? (Mukula1982:25).

The above discussion has indicated that migrated archives fall under different 


\section{Nathan Mnjama}

categories, and it is advisable that clarifications be sought whenever a discussion relating to migrated archives is done, failure to which may result in unnecessary accusations and arguments between states. The focus of this paper is on state archives that were removed from their countries of origin to western capitals. The Vienna Convention on Succession of States in respect of State Property, Archives and Debts (1983) define archives as,

all documents of whatever date and kind, produced or received by the predecessor State in the exercise of its functions which, at the date of the succession of States, belonged to the predecessor State according to its internal law and were preserved by it directly or under its control as archives for whatever purpose.

\section{The Impact caused by the removal of records from Africa}

The removal of archives from Africa to foreign countries has led to the loss of valuable records resulting in major gaps in African archival repositories. Kagombe (1980:6), the former Director of Kenya National Archives observed that 'most of the governments in the Third World or developing countries have experienced large gaps in the records and artefacts because some of these items are in Metropolitan former colonial powers'. Until recently when European countries began to adopt Freedom of Information legislation, it was virtually impossible to know the types of records that had been removed on the eve of independence. Attempts to locate migrated archives in places such as London were hampered by the 30 year closure periods and other access restrictions, but even with the enactment of the Freedom of Information Act in the UK, the government was still unwilling to disclose details concerning all the records that had been removed from its former colonies, arguing that some of these records contain sensitive information (Cobain 2013). The British Government only bowed to pressure to release information regarding removed archives from Kenya following a case filed in the UK in 2009 by Kenyan Mau Mau freedom fighters seeking for compensation for pains inflicted on them during the struggle for independence. (Lowry 1917:1). Based on the above observation, it is impossible to determine the quantity and nature of records that have been migrated from Africa to Europe.

The absence of comprehensive guides on sources relating to Africa is a major hindrance to resolving this mystery. Cases of partially processed 
records commonly referred to as backlog accumulations still exist in the Western capitals. Thanks to the Works of Thurston (1991 and 1998) on Guides such as (1) Sources for Colonial Studies in the Public Record Office. Volume I: Records of the Colonial Office, Dominions Office, Commonwealth Relations Office and Commonwealth Office, and Volume II: Records of the Cabinet, Foreign Office, Treasury and other Records; and (2) Guide to archives and manuscripts relating to Kenya and East Africa in the United Kingdom_Volume 1: Official records, Volume 2: Non-official archives and manuscripts; these works provide a glimpse of the volume of records from Kenya and East Africa that were known to be held in the UK prior to enactment of the Freedom of Information in the UK. The impact that the removal of records has had is difficult to quantify at this stage.

A survey conducted by Mnjama (2015) among Directors of National Archives in the East and Southern African region solicited various responses. When asked to comment on the impact that the removal of archives from Africa has had on their respective countries, one of the directors stated that,

the removal occasioned major gaps our archival holdings. The Country lost a natural part of its documentary heritage. This scenario evidently denied our citizens and research scholar's access to critical information and data relating to British colonial administration in our country and by extension impacting negatively on the compilation of our country's history.

Another director argued that,

We do not have a complete picture of our history and there are gaps in our holdings. A lot of money has been spent travelling to the U.K. to consult these records especially when historians and other researchers were writing books. It becomes difficult and frustrating when you have to travel to another country to consult your archives (records that rightfully belong to the African countries).

Another director claimed that,

these records, the country recognises, are of enormous potential value to the nation in terms of historical research and therefore the greatest 
justification for their return brings forth the very real possibility of rewriting our history.

The late Stephen Mwiyeriwa who served as the Director of Malawi National Archives had expressed similar sentiments when he said:

efforts are being made towards the launching of the (migrated archives) project, knowing full well that Malawi archives as the major source of study of Malawi's history cannot function effectively until the great mass of relevant papers in British repositories and also in countries such as Italy, the USA, and Zimbabwe have been copied and brought to Malawi (Mwiyeriwa 1982:34).

The transfer of archives from Africa to western capitals has resulted in Africa researchers failing to undertake any meaningful historical research without having to travel to Europe to access records that were created in Africa, while in many instances researchers conducting historical studies on various issues on Africa are able to conduct their studies without ever stepping into the African continent.

Acquiring copies of records transferred to European capitals is a major expense which African National Archives have had to bear. One director reported that the removal of archives from Africa has resulted in his government 'spending its financial resources to obtain copies of these records .... Moreover, the transfer of archives to European cities has led to the 'loss of revenue that would have accrued from the exploitation of these records for research and reference purposes. It cannot be overstated that researchers visiting local archives constitute part of the cultural tourism and contribute to local economies'.

Perhaps the greatest impact resulting from the removal of archives to western capitals is the loss of valuable records required in addressing historical injustices inflicted upon local communities by the colonial masters. Victims of historical injustices are often unable to gain redress due to non-availability of evidence to hold the perpetrators of these crimes and injustices accountable. As the Encyclopedia.Com (2020) has rightly pointed out,

Reparations for historical injustices are supported for several reasons. First, some acts were illegal under national or international law at the 
time they were committed, but the victims have been unable to secure redress for political reasons, because evidence was concealed, or because procedural barriers have prevented them from presenting claims.

This situation became evident when the Mau Mau Freedom Fighters from Kenya sought compensation from Her Majesty's Government in the UK. Their case could only be determined when secret records that had been transferred to the UK were made available (Lowry 2017:1).

Access to records held in foreign lands significantly contributes to answering questions such the 'what', the 'when', the 'who' and to a certain extent the 'why'. During the 2015 survey conducted by Mnjama, one director argued that due to the transfer of records to European cities, 'endeavours meant to hold the colonial administration accountable for its actions have been difficult to pursue due to the scarcity of information occasioned by this removal'. The value of archives as tools of social justice was clearly illustrated by Kenyan freedom fighters who sought redress at the courts in Britain following years of tortures during the struggle for independence. The freedom fighters won the case against colonial admiration upon the opening of secret records that had been migrated from Kenya to the UK. Cobain (2013) who revealed that,

During those proceedings the Foreign Office repeatedly denied the existence of a much smaller secret archive of 8,800 colonial-era documents, known as the migrated archive. It was eventually obliged to admit that this did exist, and that its contents corroborated the Kenyans' allegations about widespread acts of murder and torture by the colonial authorities.

This is a view that was supported by Bowcott (2016), who observed that while defending the Mau Mau victims, Simon Myerson, QC for the claimants, observed that 'On the orders of the governor and the commander in chief, the policies themselves were to be kept secret. On the orders of the colonial secretary and his civil servants, what was not kept secret was to be denied, and the authors of the exposure were to be rubbished. Parliament was consistently misled, so that the opportunities that would otherwise have arisen to deal with the wrongs being committed were lost'. 


\section{Nathan Mnjama}

What first distinguishes archives from libraries and museums are the records that it houses. In addition to the information contained in archival records, they also have value as evidence of actions. The evidential value of archival records gives them greater power - as legal documents, as evidence in court, and as agents of accountability. Even if one person only accesses a record, it may have wide-reaching impact. We could even argue that the preservation of the record, even if it is never accessed, can promote a culture of accountability and transparency, both as a safeguard and deterrent, in which governments act responsibly and citizens understand their rights in relation to government. This value encourages us to consider the impact of archives, beyond broadening people's perceptions and behaviors, to consider the ways in which archival documents are used to further social justice in the political arena. In fact, we hold that it is the potential of archives as a contributor to social justice that is one of its salient characteristics vis-à-vis this area of research.

\section{Efforts to Repatriate Migrated Archives to their countries of Origin}

Efforts to locate and retrieve migrated archives by African governments have been ongoing for several decades. Commenting on the state of African records removed to European countries during the Standing Conference on Library Materials in Africa conference held at the Commonwealth Institute, London, in March 1977 Sowoolo (1977:3), a former Director of National Archives of Nigeria posited that:

I would like to conclude this part of my paper with a few remarks on the issue of archives of certain African countries which now find themselves in archival institutions or libraries of the former colonial powers. This is not merely a matter of African-related archives in Europe but of authentic African archives which should be in Africa and nowhere else. The archives find themselves in Europe because they had been- for whatever reason- transferred there deliberately by the former colonial powers. The view of African Archivists on this matter is that such archives should be repatriated - in their original to their original owners. With regard to Africa-related archives, it would be sufficient if copies are provided to interested African countries, 
although some financial assistance might be needed to enable such countries acquire the copies. Indeed here is a good area where former colonial powers should be magnanimous. They should offer to make available free copies of such archives and manuscripts to African countries.

The need for African governments to gain access to all archival materials whether held locally or outside the country was perhaps best stated by Joshua Enwere (1996:20), a former director of Nigeria National Archives when he wrote saying:

Having come into government of the countries of Africa, the new elite also came face-to-face with the archival problems. They began to realise, albeit gradually, that the archives were part of the national heritage. The place of the archives as part of the cultural heritage of the nation became fully recognized by both the national government and international community. They also realised that the value of archives goes beyond the value of the cultural heritage issue that 'while one can conceive of a state without a navy for example, it is impossible to imagine one without funds and without archives which constitute these kinds of state property which are most essential and most widespread - so much so that they be said to derive from the very existence of the state.

In the East and Southern African region, concerns regarding migrated archives have been raised regularly at the Biennial Conferences of the East and Southern African Regional Branch of the International Council on Archives (ESARBICA) previously known as ECARBICA. Archivists from the East and Southern African region have passed several resolutions calling upon Britain to return the records removed from their countries. Other resolutions have advocated for the establishment of microfilming programmes of records of common interest to the region. Botswana, Kenya, Swaziland, Zanzibar, and Zimbabwe are among the countries which have attempted to locate and acquire copies of records held in Britain. A summary of the key resolutions on migrated archives passed at various ESARBICA conferences is provided below:

Table 1, ESARBICA resolutions on migrated archives, is overleaf. 
Table 1, ESARBICA resolutions on migrated archives

\begin{tabular}{|l|l|l|}
\hline Year & Venue & Resolution Passed \\
\hline 1969 & Kairobi, & $\begin{array}{l}\text { Resolved to seek through the International } \\
\text { Council on Archives the moral support of the } \\
\text { United Nations and its agencies and OAU in } \\
\text { persuading governments and national bodies } \\
\text { presently possessing such records to secure their } \\
\text { return or the supply of photocopies of them and } \\
\text { also to seek financial support of the United } \\
\text { Nations and its agencies in mounting a } \\
\text { programme of copying where governments are } \\
\text { unable or unwilling to finance themselves. }\end{array}$ \\
\hline 1974 & $\begin{array}{l}\text { Lusaka, } \\
\text { Zambia } \\
\text { archives from the former colonial powers. } \\
\text { (b) The conference recommends that } \\
\text { governments of the participating countries } \\
\text { formulate policies for the retrieval of } \\
\text { records originating from the countries of } \\
\text { East and Central Africa and held in former } \\
\text { metropolitan and other cities }\end{array}$ \\
\hline 1982 & $\begin{array}{l}\text { Harare, } \\
\text { Zimbabwe }\end{array}$ & $\begin{array}{l}\text { The seventh Biennial Conference of ECARBICA } \\
\text { endorses the proposal for the establishment of an } \\
\text { international Microfilming Assistance Fund with } \\
\text { adequate support. } \\
\text { Congratulates the government of Kenya on its } \\
\text { support of the long established and successful } \\
\text { programme of the Kenya National Archives for } \\
\text { identifying and acquiring copies of archives and } \\
\text { records located abroad relating to the history of } \\
\text { Kenya and encourages the governments of the } \\
\text { other ECARBICA countries to provide } \\
\text { comparable support, financial and technical for } \\
\text { the organization of similar programmes for their } \\
\text { countries }\end{array}$ \\
\hline
\end{tabular}




\begin{tabular}{|l|l|l|}
\hline 2003 & $\begin{array}{l}\text { Maputo, } \\
\text { Mozambique }\end{array}$ & $\begin{array}{l}\text { Bearing in mind that the issue of migrated } \\
\text { archives still remains unresolved in most of our } \\
\text { member states, this conference urges them to: } \\
\text { - } \begin{array}{l}\text { explore the possibility of imitating joint } \\
\text { programmes for the selection and } \\
\text { acquisition of migrated records, and } \\
\text { seek the support of NEPAD in promoting } \\
\text { the return of our cultural heritage from the } \\
\text { former colonial powers }\end{array}\end{array}$ \\
\hline 2005 & $\begin{array}{l}\text { Gaborone, } \\
\text { Botswana }\end{array}$ & $\begin{array}{l}\text { Bearing in mind that many archival materials } \\
\text { have left their countries of origin through various } \\
\text { ways, these conference calls for the formation of } \\
\text { a task force which will be responsible for } \\
\text { determining the extent of this problem and for } \\
\text { recommending various strategies (Gaborone } \\
\text { Botswana 2005). }\end{array}$ \\
\hline 2011 & $\begin{array}{l}\text { Maputo, } \\
\text { Mozambique }\end{array}$ & $\begin{array}{l}\text { Working collaboratively with other partners and } \\
\text { stakeholders to assist in the repatriation of the } \\
\text { remaining migrated archive }\end{array}$ \\
\hline
\end{tabular}

Source: Mnjama (2015).

Despite the many resolutions that the East and Southern African Regional Branch of the International Council on Archives has passed, there has been no major achievement in the physical return of records from Europe to the region. No wonder Mazikana (1982:31) the then Principal Archivist of Zimbabwe National Archives voiced his concerns when he pointed out that:

I am painfully aware that many resolutions have been passed on this subject and that precious few have ever materialised. It is therefore not my wish to encourage more of them which may be pious and high sounding but whose terms may be so broad as to defeat implementation, or whose aspirations may be so lofty as to elude the securing of adequate resources for implementation. From Zimbabwe standpoint, I see the issue as twofold: there is the question of central African material largely located in Zimbabwe, which is of interest to 
our neighbours and possibly to others outside this region; secondly, there is the question of the acquisition of material located outside this region, largely in the United Kingdom. What we must do is to thrash out a pragmatic, viable, and unambitious regional strategy which must take full account of our regions' aspirations and yet not gloss over the limited resources at our disposal.

Speaking at the Pan African Conference on Archival Policies and Programmes in Africa held in Abuja Nigeria in 1994, Musila Musembi, the former Director of the Kenya National Archives and Documentation Services, noted that:

Generally speaking, we have continued to receive sympathy and support from archivist and librarians in the UK and USA. We thank them most sincerely. However, attitude of the former colonial powers has not been very helpful as clearly demonstrated during the discussions on the Vienna Convention on the succession of states in respect of state property, archives and debts. This situation was also made more complicated by the position taken by developing countries mainly former colonies. Archivists, through the ICA Committee on the International Microfilming Project for developing countries, should now seek to achieve a compromise on this delicate matter (Musembi 1996:125 - 126).

The highest level at which the issue of migrated archives was ever discussed within the East and Southern African region was during the NEPAD conference held on $20^{\text {th }}$ October at Cape Town in 2003. The ministers noted that:

The archival heritage of Africa, in all its aspects, oral and written, was ignored, marginalised, transferred and denied, during the colonial era; in the post-independence era urgent competing priorities and limited resources unfortunately resulted in further neglect of our archival heritage; steps are being taken within Africa and the region to promote cooperation in the preservation of Africa's archival heritage and in the improvement of records management practices, both paperbased and electronic; and Africans have lacked access to records created in colonial capitals about African history and that this has resulted in the disempowerment of the African peoples (Boel 2008). 
The ministers recommended that,

the African Union, through NEPAD, authorise the establishment of an archival steering committee to promote cooperation in archival matters including that of ensuring that all the archival material taken from or within Africa in whatever form should be repatriated to countries of origin (Boel 2008).

Not much appears to have been accomplished by NEPAD in as far as the retrieval of migrated archives is concerned.

A key strategy that has been used to acquire copies of records transferred to western capitals has been through the use of microfilming technologies. Between 1980 and 1990, Kenya acquired large quantities of microfilm copies of Kenya-related archives from the Public Records Office (now the National Archives of UK) and other repositories. The Public Records Act of the UK at that time only permitted access to archives that were 30 years old. As a result of this, Kenya was unable to gain access to records that were created during the critical years of struggle for independence. Other African countries outside the East and Southern African region that have been involved in microfilming projects include Ghana which as early as 1976 embarked on acquiring microfilm copies of records relating to their country from the Danish Royal Archives. A Ghanaian archivist was sent to Denmark to undertake the copying project. Gadzekpo, the Director of the National Archives of Ghana, observed that this initiative resulted in greater collaboration between the Ghana National Archives and the Danish Royal Archives. He further stated that:

The Danish Royal Archives in Copenhagen seized the opportunity and informed the National Archives of Ghana of their intention to collaborate with it in the programme. While the national Archives of Ghana wanted the film to augment its holdings, the Danish Archives wanted the film for security purposes. The Danish Ministry of Culture which has ministerial responsibility for the Royal Archives, provided some funding for the programme (Gadzekpo 1996:124).

Ghana also obtained financial assistance from the Dutch Government to enable it to carry a survey of records relating to Ghana held at the Dutch National Archives, has also done extensive copying of records relating to the Basel 


\section{Nathan Mnjama}

Missionary records held in Switzerland, and large amounts of records have also been copied from the Public Record Office in Britain (Gadzekpo 1996). Tunisia too has engaged in a microfilming project. Between 1981 and 1983 major microfilming of Tunisia related records held in Paris was undertaken and approximately 2,483 of $35 \mathrm{~mm}$ reels were added to the Tunisia National Archives (Fakhfakh 1996: 127 - 128). Other African countries such as Kenya, Botswana, Zimbabwe, Malawi, and Uganda have, from time to time, sent archivists to European capitals to locate their migrated Archives. However, only Kenya has undertaken a major copying project and had its staff based at the Kenya High Commission in London charged with the responsibility of locating and copying Kenya related manuscripts held there. All the expenses for the Kenyan Copying project were borne by the Kenyan Government.

Despite the challenges encountered by African states in their effort to locate and retrieve archives held in European capitals, the archivists do acknowledge the support and cooperation they have received from repositories in Europe. Kagombe (1980:9) reported that 'the atmosphere of cooperation experienced in British institutions and the willingness of staff to go out of their way to be helpful have done much to make the National Archives staff (Kenya) programme successful this far'. Similar sentiments were expressed by Mwiyeriwa (1982:34) who posited that 'lots of invaluable advice was freely given, especially as regards the setting up of an effective copying project, based on finished or on-going examples by other countries such as Ghana, Canada, Australia, Kenya and Zanzibar'. The author, having spent six years in London copying Kenya's migrated archives, is in agreement with the sentiments expressed above. Support from professional working in archival repositories in UK was very good. However, what seems to have been lacking was the political will from the government to engage on any meaningful dialogue for the return of the migrated archives to their countries of origin.

\section{Critical Factors in the Copying and Retrieving of Migrated Archives Projects}

There are several challenges involved in locating and copying migrated archives. Hence there is a need for the formulation of clear objectives for undertaking a migrated archives project. In the case of Kenya, Thurston (1981:15) pointed out that: 
The aim of Kenya's programme has been two-fold: Firstly, it was established to provide the Kenyan government with a full picture of the extent of relevant documentation in Britain in order that priorities might be set for the supplementation of Kenya's archival holdings through a copying programme. As a result, the National Archives would be able to offer a much wider range of documentation, thereby facilitating research by government officials, development planners, and scholars, and reduce the costly journeys abroad.

Secondly, the programme was to provide researchers both in Kenya and abroad with a guide to the extent and nature of British involvement in East Africa and the location of relevant unpublished sources in Britain, many of which might fall outside Kenya's copying priorities for some years to come. Kenya could be the first African country to be able to offer this scope of comprehensive information on its relevant documentation in Britain.

In order to achieve the above objectives, the teams that conducted the surveys on Kenya's migrated archives in the UK specifically sought to accomplish the following objectives:

(i) To compile comprehensive information on the location, nature, and extent of Kenya/East Africa related record holdings in British libraries and repositories,

(ii) To assess the attitude in Britain towards a programme of document retrieval,

(iii) To evaluate the problems and issues facing the programme which require policy decision by National Archives, and

(iv) To contact as many individuals as possible who could supply suggestions on the location of various types of records (Kagombe 1980:8).

The author was not only a member of the survey team, but between April 1980 and December 1985 served as the Cultural Attaché responsible for the copying project at the Kenya High Commission in London.

The need to develop clear goals and objectives when implementing a migrated project was stressed by Khamis (2000) when sharing the experiences 


\section{Nathan Mnjama}

gained by Zanzibar National Archives when retrieving records from Britain and India. Khamis (2000:64f) stressed that:

It is worth noting that from the outset, a project to retrieve migrated archives is extremely demanding in terms of both financial and human resources. It is important to define your objectives and scope of the project properly, which in turn will determine the amount of financial and human resources needed to carry out the project. Considering the amount of funds available, we decided to implement the project in different phases. Due to financial limitations, the project focused mainly on photographic collection relating to Zanzibar, and in a few cases other documents such as old maps were reproduced. ... Failure to define your scope may result in time and financial wasting, duplication of records, etc.

In the first instance, the location of records held in foreign lands can be a daunting task for researchers and archivists who might be visiting European capitals for the first time. Many of the Guides containing archival resources held in foreign lands are either dated or in need of updating. In other instances, guides to sources on African studies held in European repositories are nonexistent or are not accessible easily. Also not much effort has been made by African bibliographers in providing detailed information on archival collections held abroad. This may be partly due partly to the absence of basic retrieval tools such as detailed accession registers and due partly to the existence of unprocessed collections and non-availability of digitised collections in archival websites. Moreover, contrary to ICA Principles on Access, which demand that 'institutions holding archives [should] make known the existence of the archives, including the existence of closed materials' many archival institutions in the West have made little effort to publicise the existence of migrated archives in their custody. For many years, UK denied the existence of the Foreign and Commonwealth secret archives held at Hanslope Park, London.

Adequate knowledge of one's own archival holdings is a prerequisite to a successful migrated archives project. Khamis (2000:65) from Zanzibar National Archives advises that,

the first and foremost step is to have a clear understanding of your 
repository collections. Unless one has organized and documented archives, it would be not be easy to implement the project effectively.

It is of vital importance that adequate research be undertaken to ascertain the availability of records locally before making any request for copies from foreign repositories or even making any false accusations of records stolen or migrated to another country. The embarrassment that may arise from false accusations may jeopardise future support and collaboration from foreign repositories.

The cost factor is often one of the reasons that archives removed from Africa remain inaccessible to the vast majority of African scholars. Starting with problems related to obtaining a visa to travel to Europe, travelling expenses, and living expenses when undertaking research in foreign countries more than often becomes a limiting factor and denies African scholars effectively the opportunity to engage with information sources held overseas even where these are available. Added to this, copyright and other legal issues such as privacy laws may also restrict access to certain types of records held abroad.

Winn (2015:10) in her article on Ethics of Access in Displaced Archives indicates that 'Legal rights to privacy are particularly difficult to define in the case of displaced archives because access may be informed by multiple legal, political, and cultural contexts'. Winn (2015:10f) went on to state that 'Reconciling trans-boundary legal frameworks does not fully address ethical questions around access, however creators, subjects, users, and archivists working with displaced materials often maintain different ideas about what kinds of information should be privileged. Archival institutions are more willing to accept limited restrictions to access in the name of personal privacy, intellectual property, legal investigations, and national security, but current international norms fail to reflect the interests of the creating communities'.

\section{Conclusion}

The above discussion has revealed that the problems of records removed from Africa remain unresolved five decades after many of the African countries gained independence. Past efforts to address problems of migrated archives at the international level by UNESCO, the International Council on Archives and 


\section{Nathan Mnjama}

the United Nations, through the formulation of an international instrument such as the Law of Succession on State Property, Archives and Debts, have not yielded the desired results. It is perhaps time for colonial governments to acknowledge publicly that it was wrong to transfer records from their colonies and not institute measures for the return of the concerned records to the places of origin. This should be done through consultation with the affected countries.

A respondent from a recent survey conducted by Lowry (2018:25) recommended that African government should pursue bilateral agreements pointing out that,

I personally believe that having service level agreements [SLA] between current custodians and the original owners of the displaced Archives can help a lot to harmonise the problems involved. These agreements can in the interim enable the original owner to have access to her/his Archives until a decisive move is undertaken to repatriate the archives to the original owner. Basically, I would advocate for open access to the original owner until the ultimate transfer decision is made. This would reduce or solve on the conflict.

African governments are therefore encouraged to pursue this course of action if at all any meaningful solution is to be found to problems associated with migrated archives which have dodged African nations from the time they gained their independences and is bound to remain the unfinished business for Directors of National Archives for a considerable number of years to come. In the same vein, Western countries are also encouraged to formulate strategies of opening all archives that are still classified as secret. For instance, in the UK, the processing of the so called secret archives (which includes some of the records taken from the colonies) has been progressing at such a slow pace in the UK prompting Cobain (2013:1) to come to the conclusion that:

It will be quite a task. Declassification of the migrated archive has taken two and a half years, with the final tranche of documents due to arrive at Kew next month. At that rate, clearing up the special collections would take around 340 years.

Failure to process such records and making them available for public inspections guarantees that the migrated archives issue remains the unfinished 
business for generations to come.

Above all African countries are encouraged to put measures in place that will ensure that digitisation projects, many of which are sponsored from western capitals, are well managed, and digital images produced from these programmes are well preserved within the African continent. Failure to do so may result in digital colonisation in which a few years from now, African governments will be running to obtain copies of digital collections that were acquired through the use of digital technologies.

\section{References}

Archives-Libraries Committee Resolution on Migrated Archives 1977. African Studies Newsletter 10,6. Available at:

http://www.innovation.ukzn.ac.za/InnovationPdfs/No34p71Resolution.p df

Bedjaoui, M. 1976. Eighth Report on Succession of States in Respect to Matters Other than Treaties, 54. Cited in Montgomery, B. 2015. Reconciling the Inalienability Doctrine with the Conventions of War. The American Archivist 78, 2: 288 - 316.

Boel, J. 2008. Resolutions of the Delegates' Meeting of the International

Council on Archives Cape Town 24 October 2003. Available at: http://www.unesco.org/archives/hrgnews/hrgpages.php?id_details=2

Bostock,W n.d. Archiving in Southern Africa: Psychological, Ethical and Technological Aspects. Available at:

http://anthroglobe.info/docs/Archiving\%20in\%20Southern\%20Africa.ht $\underline{\mathrm{m}}$

Botswana National Archives n.d. Migrated Archives: Bridging the Gap in our

National Documentary Heritage. Gaborone: Botswana National Archives.

Bowcott, O. 2016. Mau Mau Rebellion Victims Claim Parliament was Misled over Torture. The Guardian 22 May 2016. Available at:

https://www.theguardian.com/world/2016/may/23/mau-mau-rebellionkenyan-victims-compensation-claim

Canadian Council on Archives 2012. Memorandum on the Elimination of the

National Archival Development Program. Available at:

http://www.cdncouncilarchives.ca/CCAFactSheet v1.2Updated EN.pdf

Circular Letter Sent to the Colonies and Signed by L.S. Amery. Swaziland 
National Archives Files RCS 903/14 and RCS 1 - 29 82/29 Custody of

Public Records and Destruction of Public Records. Reproduced in ESARBICA Journal 6 (1983) pp. 80 - 83.

Circular Letter W. Ormsby Gore to the Officers Administering the

Governments of ... Swaziland National Archives Files RCS 903/14 and

RCS 1 - 29 82/29 Custody of Public Records and Destruction of Public

Records. Reproduced in ESARBICA Journal 6 (1983) pp. 80 - 83.

Cobain A 2013. Foreign Office Hoarding 1m Historic Files in Secret Archive.

Available at: https://www.theguardian.com/politics/2013/oct/18/foreign-

office-historic-files-secret-archive .

Encyclopedia.Com 2020. Historical Injustices. Available at:

https://www.encyclopedia.com/international/encyclopedias-almanacs-

transcripts-and-maps/historical-injustices (Accessed on 20 May 2020.)

Enwere, J. 1996. Archival Legislation, a Watershed in the Development of

Archives and Records Management in Africa. Janus: Archival Review 20

- 26. The quotation cited is from Mohammed Bedjaoui, Eight Report on Succession of States in Respect of Matters Other than Treaties: Draft Articles with Commentaries Document AD/DN4?229 of 8th April 1976, United Nations, 1976.

Fakhfakh, M. 1996. The Microfilm Programme of Tunisia. Janus: Archival Review 127 - 128.

Foreign and Commonwealth Office 2011. The Cary Report on the Release of Colonial Administration Files. Available at:

https://assets.publishing.service.gov.uk/government/uploads/system/uplo ads/attachment_data/file/625667/cary-report-release-colonialadministration-files.pdf (Accessed on 24 February 2020.)

Gadzekpo, C.K. 1996. The Microfilming Programme of Ghana. Janus: Archival Review 123 - 124.

Garaba, F. 2011. Provenance, Identification, Restitution and Management of the Liberation Struggle Heritage in the ESARBICA Region. Journal of the Society of South African Archivists 44: 26 - 43.

Hiribarren, V. 2017. Hiding the Colonial Past? A Comparison of European Archival Policies. In Lowry, J. Displaced Archives. London: Routledge.

International Council on Archives 1995. Reference Dossier on Archival

Claims. Available at:

https://www.ica.org/sites/default/files/ICA 1995 Reference-Dossier-onArchival-Claims_EN.pdf 
Kagomee, M. 1977. A Note on Archives as a Source of Information for Research Development in Africa with Special Reference to Kenya in Progress in African Bibliography: SCOLMA conference [held at the] Commonwealth Institute, London, 17 - 18 March 1977, Proceedings. London: SCOLMA.

Kagombe, M.D. 1980. Kenya's Restitution of Archival Claims. African Research and Documentation 23: 6 - 9.

Kcskemeti, C. 2017. Archives Seizures: The Evolution of International Law.

In Lowry, J. Displaced Archives. London: Routledge.

Khamis, S.K. 2000. Migrated Archives Project. ESARBICA Journal 19: 64 67.

Kukubo, J.R. 1990. Replevin and Export Control of Archival Materials:

Legislative Provisions in ESARBICA. ESARBICA Journal 12: 3 - 27.

Kumar, V. 1991. Critical Analysis of Law of State Succession in Respect of Matters to the Exclusion of Treaties. PhD Thesis, Himachal Pradesh University. Available at: http://hdl.handle.net/10603/129013 (Accessed on 10 November 2020.)

Lowry, J. 2017. Displaced Archives. London: Routledge.

Leisinger, A. 1982. Disputed Archival Claims: A Persistent and Urgent

Problem. ECARBICA 7. Seventh Biennial Conference and Seminar of the

East and Central Africa Regional Branch of the International Council on Archives, Harare, 13 - 17 September 1982.

Lowry, J. 2018. 2018 Survey Report: Report to the International Council on Archives' Expert Group on Shared Archival Heritage, Liverpool University Centre for Archive Studies September 2019.

Lowry, J. 2019. Displaced Archives: Proposing a Research Agenda. Archival Science 19: 349 - 358.

Macphee, G. 2012. Secret British Colonial Archive Finally Released. Counter Punch 20 - 22 April 2012. Available at:

http://www.counterpunch.org/2012/04/20/secret-british-colonialarchive-finally-released/

Mazikana, P. 1982. Migrated Archives: The Position of Zimbabwe. ECARBICA 7. Seventh Biennial Conference and Seminar of the East and Central Africa Regional Branch of the International Council on Archives, Harare, 13 - 17 September 1982.

Mazikana, P.C. 1977. Migrated Archives: The Position of Zimbabwe. ECARBICA 7 Seventh Biennial Conference and Seminar of the East and 
Central Africa Regional Branch of the International Council on Archives, Harare, 13 -17 September 1977.

Mazikana, P.C. 1996/ 1997. Africa: Information Worldwide Available at: http://www.unesco.org/webworld/wirerpt/wirenglish/chap11.pdf

Mnjama, N. 2000. The Records of the East African Community. African Research and Documentation 82: 3 - 12.

Mnjama, N. 2007. A Chronology of the East and Southern African Regional Branch of the International Council on Archives Resolutions, 1969 2005. ESARBICA Journal 26: 133 - 180.

Mnjamaa, N.M. 2008. The Orentlicher Principles on the Preservation and Access to Archives Bearing Witness to Human Rights Violations. Information Development 24, 3: 213 - 225.

Mnjama, N. 2015. Migrated Archives: The African Experience. Journal of the South African Society of Archivists 48, 45, 54. Available at:

file:///C:/Users/mnjamanm/Downloads/129271-350035-1-PB.pdf

Mukula, P.M. 1982. Migrated Archives: The Position of Zambia ECARBICA

7. Seventh Biennial Conference and Seminar of the East and Central

Africa Regional Branch of the International Council on Archives, Harare, 13 -17 September 1982.

Musembi, M. 1982. Retrieval of Migrated Archives: The Kenyan Experience. In ECARBICA 7. Seventh Biennial Conference and Seminar of the East and Central Africa Regional Branch of the International Council on Archives, Harare, 13 -17 September 1982.

Musembi, M. 1996. The Microfilm Programme of Kenya. Janus: Archival Review 27 - 33.

Musembi, M. 1986. Development of Archival Services in East Africa. In Kukubo, R.J. (ed.): Proceedings of $9^{\text {th }}$ Biennial General Conference, Mbabane, Swaziland, 3 - 8 November 1986. University Press of Lesotho for East and Southern Africa Regional Branch of the International Council on Archives, 1988, pp. 115 - 134.

Mwiyeriwa, S.S. 1982. The National Archives of Malawi and the Problem of Migrated Archives. African Research and Documentation 30: 32 - 33.

Namihla, E.N. 2015. Colonial Gaps in Post-Colonial National Archive:

Record Keeping and Missing 'Native Estates' in Namibia. PhD Thesis, University of Tampere, Finland,

Nsibandze, N. 1996. Southern African Archives in Exile. SA Archives Journal 38: 84 - 87. 
Parson, N. 2006. Unrafelling History and Cultural Heritage in Botswana. Journal of Southern African Studies 32, 4: 67 - 82.

Ramokate, K. 2004. Botswana Recovers Migrated Archives. Mmegi 15 January 2004. Available at:

http://allafrica.com/stories/200401160269.html

Rawlings, G. 2015. Lost Files, Forgotten Papers and Colonial Disclosures: The 'Migrated Archives' and the Pacific, 1963 - 2013. Available at:

https://www.tandfonline.com/doi/full/10.1080/00223344.2015.1048585

Society of American Archivists 2005. Glossary of Archival and Records Terminology. Available at:

http://www2.archivists.org/glossary/terms/m/migrated-archives

Sowoolo, S.O. 1977. Archives and Manuscripts Relating to Africa. In Progress in African Bibliography: SCOLMA Conference [held at the] Commonwealth Institute, London, 17 - 18 March 1977, Proceedings. London: SCOLMA, 1977, p.3.

Thurston, A. 1981. The Kenya Copying Project. African Research and Documentation 27: 15 - 20.

Thurston, A. 1998. Sources for Colonial Studies in the Public Record Office. Volume I: Records of the Colonial Office, Dominions Office, Commonwealth Relations Office and Commonwealth Office, HMSO, London 1995.

Thurston, A. 1998. Sources for Colonial Studies in the Public Record Office.

Volume II: Records of the Cabinet, Foreign Office, Treasury and other Records, HMSO, London.

Thurston, A. 1991. Guide to Archives and Manuscripts Relating to Kenya and East Africa in the United Kingdom. Volumes I and II. London: Hans Zell Publishers.

United Nations 2005. Economic and Social Council. Commission on Human Rights. Sixty-first session. Item 17 of the provisional agenda. Promotion and Protection of Human Rights. Impunity. Report of the independent expert to update the Set of principles to combat impunity, Diane Orentlicher. Addendum: Updated Set of principles for the protection and promotion of human rights through action to combat impunity. E/CN.4/2005/102/Add.1 8 February 2005. Available at: https://documents-dds-

ny.un.org/doc/UNDOC/GEN/G05/109/00/PDF/G0510900.pdf?OpenEle ment (Accessed on 3 December 2020.) 
Universal Declaration on Archives 2012. Available at: https://www.ica.org/sites/default/files/20190510_ica_declarationunivers elle en-print $0 . p d f$

Vienna Convention on Succession of States in Respect of State Property. Archives and Debts 1983. Available at:

http://legal.un.org/ilc/texts/instruments/english/conventions/3_3_1983.p df

Winn, S.R. 2015. Ethics of Access in Displaced Archives. Provenance, Journal of the Society of Georgia Archivists 33, I: 6 - 13. Available at: https://digitalcommons.kennesaw.edu/cgi/viewcontent.cgi?article=1410 \&context=provenance

Professor Nathan Mnjama Department of Library and Information Studies University of Botswana Gaborone Botswana mnjamanm@mopipi.ub.bw 